\title{
Trans-nationalizing the African Public Sphere: What Role for Trans-border Languages?
}

\author{
Maimouna Barro*
}

\begin{abstract}
At a time when the notion of 'trans-national public spheres' is gaining more and more currency in academic circles, the role played by languages, and trans-border languages in particular, cannot be ignored in our attempts to rethink the African public sphere. In the African context, language has been a major factor in determining cultural and ethnic identity among various groups, whether they live within the same nation-state or are territorially dispersed. This situation problematizes the idea of a Westphalian citizenry resident in a national territory, and challenges the assumption that languages map onto states. This paper focuses on the Fulfulde language - a trans-border language spoken across several national boundaries in West Africa - and assesses ways in which trans-border languages contribute to the emergence of a transnational public sphere in Africa.
\end{abstract}

\section{Résumé}

À une époque où la notion de «sphères publiques trans-nationales » se répand de plus en plus dans les milieux universitaires, le rôle joué par les langues en général et les langues transfrontalières en particulier ne peut être ignoré dans nos efforts pour repenser la sphère publique africaine. Dans le contexte africain, la langue a été un facteur important dans la détermination de l'identité culturelle et ethnique au sein de différents groupes, qu'ils vivent au sein de le même État-nation ou qu'ils soient éparpillés sur des territoires. Cette situation rend problématique l'idée d'une citoyenneté westphalienne résidant sur un territoire national, et conteste l'hypothèse que les langues correspondent plus aux États. Ce document met l'accent sur la langue fulfulde -une langue transfrontalière parlée à travers plusieurs frontières nationales en Afrique de l'Ouest- et évalue les moyens par lesquels les langues transfrontalières contribuent à l'émergence d'une sphère publique transnationale en Afrique.

* Center for African Studies, University of Illinois, Urbana-Champaign, USA. Email: barro@illinois.edu 


\section{Introduction}

The public sphere as conceptualized by Jurgën Habermas rested on several institutional presuppositions that were all implicitly Westphalian. One of Habermas's presuppositions regarding the public sphere was that of a single national language which, in his view, was supposed to be the linguistic medium of the public sphere and public communication. This perspective problematizes the notion of a democratic public sphere in Africa where African societies are for the most part multi-linguistic. In addition, during most of the post-independence era, there has been very minimal progress in the promotion of indigenous African languages, the languages of African masses, whereas colonial languages continue to have the status of official languages and remain the primarily tools of communication in public institutions. However, despite the fact that the local African languages have been put on the backburner by both colonial and post-colonial governments for a long time, they continue to play a vital role in the lives of African communities both within and beyond their national boundaries.

At a time when several African countries are witnessing an increasing democratization of political structures and when there has been notable progress and growth in independent and pluralistic media, debate about the public sphere and public opinion in Africa is gaining a special resonance in academic circles. The rapid development of mass media in Africa characterized by a pluralistic media and participatory forms of dialogue and expression gives voice to marginalized and isolated communities in both national and transnational public spheres. However, the public sphere is by no means new to Africa. Examples from various ethnic groups in Africa suggest that, traditionally, there existed a public opinion that limited the power of the political elite, which was indeed comparable to Habermas's concept of a coffeehouse culture of eighteenth-century England. Even though social categories such as elders, men and members of the nobility enjoyed privilege in public debate, groups all along the social ladder were also given some space to voice their opinions on matters pertaining to their communities' public life. Public entities such as the Battu Futankoobe (General Assembly of Pulaar People) among the Pulaar people of Fuuta-Tooro along the Senegal River Valley, or the Pencu Lebu (General Assembly of Lebu People) among the Lebu people in the Cap-vert region in Senegal both suggest that participatory forms of dialogue in the public space existed.

In our day and age, the core feature of the modern public sphere is a common and publicly accessible space such as a marketplace, pub, newspaper, radio, television or internet, which serves the purpose of framing public opinion. This paper is premised on the assumption that whatever form 
of communication is used in order to frame public opinion, the language or languages of the public sphere, whether in print or in oral form, constitute a key element in our efforts to rethink the public sphere. The public sphere constitutes a key element in any society that calls itself democratic. Public debate in a public space can only occur when there exists a free exchange of information and ideas, when citizens can voice their opinions on issues of public concern and are able to transmit their public will to official authorities, and when they have the means to influence decision-making.

There is little doubt that the continued status of colonial languages as official languages in most of Africa - a legacy of colonialism that independent African governments carried on - constitutes a major obstacle in attempts to create a democratic public sphere. However, language has always played an important role in defining group identity. Tocqueville, in Democracy in America, argues that 'language is perhaps the most enduring link which unites man'. It is true that a common language has not always translated into group cohesion and cooperation, but evidence from several places in the African continent suggests that even groups that were arbitrarily partitioned by colonial boundaries are often brought together by their common linguistic, ethnic, and cultural bonds. Deeming language 'the element of culture par excellence' Chumbow (2005) regards a common language as an instrument for bringing people together and for achieving peace and harmony between nations in Africa, and argues that trans-border languages have a major role to play in achieving pan-African ideals and the goals of continental unity. Chumbow states:

Despite the disruptive effect of arbitrary boundaries on the cultural and ethnic unity of partitioned peoples, however, they quite often cultivate and reinforce pre-partition networks of intra-group or intra-ethnic relations and in some cases (at least historically) they consider the boundary as binding only on the colonial powers or present-day governments and not on their own internal relations with their kith and kin, which they consider 'inviolable' (p.183).

This paper focuses on the Fulfulde language, a transnational African language spoken in roughly fourteen countries throughout the Sahel region of West Africa to the borders of Eastern Sudan. The first part of the paper demonstrates the existence of a transnational Fulfulde cultural heritage, very apparent in the concept of Pulaagu. It then traces the birth of the Pulaar literacy movement in Senegal and Mauritania, and examines the socio-historical and political contexts that contributed to its development. It examines the ways in which the movement around the Pulaar language, a movement whose beginnings started outside the borders of Senegal and Mauritania, has been used to influence social structures and political institutions at home in 
both countries, especially in Mauritania where literacy in Pulaar was the medium through which Pulaar populations voiced their dissatisfaction with a racist political regime and its policies of 'arabization'. The last part of the paper looks at the emergence of a global Fulfulde civil society, which is increasingly becoming a forum for real issues affecting Fulfulde communities. In this paper, the terms 'Fulfulde language' and 'Fulbe people' will be used, respectively, to refer to the language and its people throughout the West African region and beyond, while the terms Pulaar language and Pulaar people refer specifically to the language and its speakers in Senegal and Mauritania, the region known as Fuuta-Tooro.

\section{A Transnational Fulfulde Cultural Space}

To study a society, its traditions and its evolution, literature - whether written or oral - provides a good starting point. Fulfulde and its mutually intelligible dialects represent the language of roughly 25 million people across several national boundaries in West Central Africa. Over the centuries, Fulbe people migrated throughout the Sahel and Savannah regions of West Africa and evolved into many subgroups with a variety of designations corresponding to specific geographical zones where they were concentrated as Fulbe, Fellaata, Fulakunda, Gorgaabe, Haalpulaar, and Woodaabe, to name just a few. Presently, they live in communities throughout much of West and Central Africa - from Senegal to Cameroon - and are dispersed as far east as Sudan and Ethiopia. The Fulbe people are concentrated in six major west African regions where they historically had an impact, namely Adamawa (Cameroon), Kanem-Bornu (Chad), Masina (Mali), Fuuta-Jallon (Guinea), Fuuta-Tooro (Senegal and Mauritania) and Sokoto (Nigeria).

There has been a long tradition of writing in Fulfulde in the above mentioned eighteenth and nineteenth centuries states, which were also major Islamic foyers. The Fulfulde language is indeed one of the most written African languages. With the progressive expansion of Islam and Q'uranic education, writing in Fulfulde using the Arabic script - a system of writing known as ajami - was developed, leading to the emergence of a small literate class of people. Fulfulde ajami texts are primarily religious texts dealing with theological, juridical, and political content, and are only accessible to a small minority of Fulfulde speakers. However, by localizing the Arabic language, this literate elite was able to touch a larger public. This written literature is shared by the entire pan-Fulfulde region. According to Christiane Seydou (2000), this literature was developed in the context of major state formations in Fulfulde history from Senegal to Cameroon. Seydou explains that these political formations throughout Fulbe people's history have in fact contributed 
to the progressive settlement of a people who traditionally were nomads and who were now organized politically, creating more favourable conditions for the development of a literate class and the expansion of literacy.

While the Fulfulde written literature was the work of a small elite of Fulbe scholars and was only accessible to a small audience of literates in Arabic, forms of writing based on oral traditions encompassed a rich and varied cultural heritage throughout the Pan-Fulfulde region and transcended political borders. These productions represent different genres - from proverbs, folktales, riddles, and poems to epic novels - which transmit important aspects of Fulbe people's cultures and traditions. An epic novel such as the Senegalese Yero Dooro Jallo's Ndikkiri Jom Moolo (Ndikkiri the Guitarist), the first epic novel written in Fulfulde, is primarily based on Fulfulde oral culture.

Christiane Seydou emphasizes the importance Fulbe people attach to their oral literary expressions and places language and the art of the verb at the heart of this cultural and aesthetic investment. She defines language among Fulbe people as 'le seul bien aliénable, toujours présent et disponible meme dans l'isolement ou la solitude' [the only unalienable asset, always present and available even in one's isolation or loneliness] (p.63). Lilyan Kesteloot takes the issue further and discusses the centrality of oral literary productions throughout the West African Fulbe diaspora. This literature relates more to the ethnic group and the language it represents than to the borders of the modern state, for its linguistic and cultural characteristics transcend political borders. Referring specifically to the question of the pan-Fulfulde oral traditions, Kesteloot writes:

Le caractère artificiel des frontières coloniales qui délimitent aujourd'hui les États africains a été maintes fois dénoncé. Mais c'est lorsqu'on étudie les espaces parcourus par la littérature orale qu'on prend conscience de leur réelle absurdité. Dire, par exemple, que la littérature sénégalaise s'arrête à Podoor ou ne dépasse pas la Falémé est absurde, pour qui sait que Sambà Gelaajo appartient aux Tukuloor des deux rives, et que Sunjata est chanté depuis la Gambie jusqu'à Bobodioulasso, en passant par la Casamance, la Guinée, la Côte d'Ivoire et le Mali ... Ainsi la littérature pël du Sénégal marche avec les transhumants jusqu'au Niger, à travers tout le Sahel ... (Kesteloot, Unpublished paper).

[The artificial nature of colonial borders dividing African countries today has been denounced many times. However, it is when one studies the areas covered by oral literature that one is conscious about their absurdity. Arguing that Senegalese literature ends in Podor or that it does not go beyond the Faleme region is absurd to anyone who knows that Samba Gelaajo belongs 
to Pulaar speakers on both sides of the river, and that the epic of Sundiata is sung from the Gambia to Bobodioulasso, via Casamance, Guinea, the Ivory Coast and Mali. Thus, Fulfulde literature crosses the borders with pastoralists up to Niger and throughout the Sahel region ...]

Any assessment of the of the vast panorama of Fulfulde oral literature cannot ignore the significant contributions made by the well known scholar Amadou Hampate Ba in promoting Fulfulde and West African oral traditions. Originally from Mali and born to an aristocratic Fulbe family in Bandiagara the capital of the pre-colonial Tekruur kingdom - he is considered one of the major intellectual and literary figures of the twentieth-century Africa. As a storyteller, poet and historian, this self-made intellectual is considered one of the most gifted and multi-disciplinary scholars of his time. Today, there exists a considerable interest in Hampate Ba's published works, which have been translated from French into several European languages, as well as Japanese. A historian, collector and translator of oral and ethnological texts, he was also a poet in his native Fulfulde and the author of prize-winning and widely read literary works. He was also appointed to the UNESCO Executive Council where he pressed for the systematic collection of African oral teachings and for the rescue of African oral traditions, not only because of their cultural value but also because they enshrine a vast sum of historical, religious, philosophical, scientific and literary knowledge. He claimed to be a medium for preserving, transmitting, and translating this oral knowledge and art of Africa to various audiences. Hampate Ba is perhaps best known for his statement: 'En Afrique, quand un vieillard meurt, c'est comme une bibliothèque qui brûle' [Every time an old man dies in Africa, it is as if a library has burnt down]. On the dichotomy between writing and orality, Hampate Ba (1972)quoting his philosophical master the Malian Sufi mystic Thierno Bokar points out: 'L'ecriture est une chose et le savoir en est une autre. L'écriture est la photographie du savoir, mais elle en ait pas savoir lui-même. Le savoir est une lumière qui est en l'homme, l'héritage de ce qui lui a été transmis' [Writing is one thing and knowledge is another. Writing is the photographing of knowledge, but it is not knowledge itself. Knowledge is light within man, the heritage of what has been transmitted to him.]

Although written in French, his entire work is emblematic of a deep Fulfulde cultural heritage rooted in his native Masina customs and traditions. The same observation can also be made about the literary productions of, for example, francophone Senegalese writers who ethnically and culturally belong to Fuuta-Tooro, which has led some critics to characterize their literature as regionalist or as littérature de terroir. Though classified under Senegalese and Mauritanian Francophone writers, novelists such as Cheikh 
Ahmidou Kane (in L'aventure Ambiguë or Les Gardiens du Temple), Abdoulaye Kane (in Markere), Tene Youssouf Gueye (in Rellâ ou les Voies de l'Honneur) and Moussa Lam (in La fièvre de la terre), give a vivid representation of Fuuta-Tooro as a territory and a cultural space that transcends the political borders of Senegal and Mauritania.

Writing in Fulfulde is still very prevalent in Fulbe circles of West Africa and continues to be greatly influenced by Fulfulde oral traditions. This has led critics to argue that alongside these two modes of literary productions, a third and more 'modern' literary movement has emerged in the last twenty five years. As Mohamadou (2000) explains, it is in Fuuta-Tooro that the weight of this literary movement has been most felt and is most influential. Actors in this literary movement have also been at the forefront of the Pulaar grassroots movement in Senegal and Mauritania, creating a momentum in the formation of organizations and, therefore, contributing to the development of an increasingly global network of Fulfulde speakers.

\section{The Pulaar Grassroots Movement in Senegal and Mauritania}

Fuuta-Tooro corresponds to the middle valley of the Senegal River in presentday northern Senegal and southern Mauritania. It is the territory of the Haalpulaaren or those who speak Pulaar. The Pulaar people are also referred to as Toucouleurs, a designation that derived from Tekruur, an ancient Islamic kingdom, which prospered roughly parallel to Ghana during the ninth and tenth centuries. Strong kinship ties have, to this day, brought Pulaar communities together, making the boundary between the two groups only an artificial one, regionalizing an area that encompasses both sides along the Senegal River.

In Senegal, Pulaar is spoken by roughly one-third of the Senegalese population. The use of Wolof as the lingua franca of the country was reinforced by the French colonial administration, as it became the primary language of trade and business near towns and ports throughout the country. Those who speak Wolof chose it as the language of the majority in Senegal for practical reasons. Although recent attempts to promote Wolof as the national official language of Senegal have triggered strong reactions from militant speakers of other languages - especially from Pulaar speakers Wolof has naturally grown into a lingua franca and is considered by many as one of the most important homogenizing factors of the Senegalese society.

In Mauritania, Pulaar is spoken by a much smaller portion of the population, estimated at around five per cent of the total number of three million Mauritanians. However, because the promotion of Pulaar and other local languages spoken by black Mauritanians - namely Wolof and Soninke have purposely been pushed to the back in favour of the arabization of the 
school system and the arabization, or 'beydanization', of public services (Ly 1997), a very strong Pulaar movement in Mauritania has come about, inspired by acute political problems. Militancy around the question of the promotion of Pulaar in Mauritania led to the creation of l'Association Pour la Renaissance du Pulaar en Republique Islamic de Mauritanie (ARPRIM) [Association for the Revival of Pulaar in the Islamic Republic of Mauritania] in 1974, also known under its Pulaar name as Fedde Bamtaare Pulaar e Muritani [FBPM]. This association was recognized by all public institutions in 1976 and played a pioneering role in the promotion of Pulaar culture. It opened Pulaar literacy classes for the Pulaar masses, and strongly advocated the necessity to introduce local languages in the Mauritanian school system. A major step in the evolution of ARPRIM the creation of Institut des Langues Nationales [Institute of National Languages] in 1979 and the eventual introduction of Pulaar, Soninke and Wolof languages in the school system. In addition, ARPRIM established the magazine Fooyre Bamtaare, the only magazine in a national language other than Arabic. The Pulaar movement in Mauritania led to the emergence of activists who contributed as language activists, journalists, poets and broadcasters, such as Mammadu Samba Joob (most commonly known under the name Muurtudo or the Rebel), Tene Youssouf Gueye, and Ibrahima Sarr. Each played an instrumental role in fighting for the promotion of the Pulaar language and the improvement of the social and economic conditions of their people, and they used the struggle over language and cultural identity as a tool for changing social structures and political institutions. Quoting Ly (1997), Fagerberg-Diallo (2001) notes:

In Mauritania, teaching in national languages had a particular character. It was the result of a struggle mobilized by a powerful grassroots movement for cultural identity whose origins went back to the 60s [the moment of independence]. Just after independence, the black African population of Mauritania mobilized themselves to fight against the arabization of the school system, to the detriment of French, and against the beydanization of public services (p.161).

Indeed, even though ARPRIM founders were interested in revitalizing Pulaar from a cultural perspective, their militancy led them to jail, exile and death (in the case of Tene Youssouf Gueye) at the hands of the Mauritanian Arab government.

In Senegal as well, a Pulaar national association by the same name was created a few years later, which shared the same literacy goals as Mauritania's ARPRIM. Senegal's Association Pour la Renaissance du Pulaar (ARP) was founded in 1982, although it had its roots in a non-official Pulaar cultural association formed in 1964 by Pulaar-speaking students and workers in Dakar. 
ARP-Senegal was very much influenced by the Pulaar literacy movement in neighbouring Mauritania and, through the years, the two movements have closely joined hands in their struggle to fight for the Pulaar cause.

In both Mauritania and Senegal, several factors have contributed to the development of Pulaar literacy. First, as early as 1966, UNESCO sponsored a meeting that was held in neighbouring Mali for the promotion of major West African languages spoken across national boundaries such as Fulfulde. An orthography was suggested for Fulfulde and was recognized internationally. This was a major development, for an internationally recognized orthography was a necessary step if countries were to share texts and publications. Second and most importantly, the mid-1960s also saw the development of a popular Pulaar grassroots movement led mainly by Pulaar speakers in universities in the Middle East, namely in Cairo, Kuwait, and Saudi Arabia, but they also included other Fulfulde students originally from other parts of West Africa. The Pulaar literacy movement presents an interesting case, for its beginnings did not take place in these two countries. Instead, a group of Pulaar intellectuals living in Cairo during the 1960s and 1970s started the movement and spread it among Pulaar-speaking students and workers who migrated to France in the 1980s before it was to have an impact in both Senegal and Mauritania. A federation of associations for the promotion of the Pulaar language was founded under the name Kawtal janngoobe Pulaar e Leydeele Aarabeebe [Association of Pulaar students in Arab Countries]. This marked the beginning of a Pulaar diasporic movement away from Fuuta-Tooro. Activists originally from both sides of the border experienced a heightened diasporic consciousness that, as will be discussed later, expanded beyond the borders of Senegal and Mauritania.

The experience of emigration, especially in France, had in fact a fascinating effect on the Pulaar speakers' motivation to learn. The majority of workers in France participated in the Pulaar literacy classes. As Fagerberg-Diallo (2001) points out, living in a highly literate society reinforced their motivation to learn to read and write, whereas their experiences as a group functioning within the margins of French society and public sphere forced them to cling to their language and cultural identity. This takes us back to the point made earlier in reference to Kestleloot's argument about language and the lonely, isolated pastoralist, the notion that 'it is the only unalienable asset, always present and available even in one's isolation or loneliness'. Pulaar activists in Mauritania and Senegal were at the forefront of this movement. They made scholarly contributions ranging from writing novels and poems in Pulaar to establishing various language magazines, newsletters and broadcasting services. 
One of the most active and charismatic militants was the late Yero Dooro Jallo. In fact, his trajectory as a Pulaar activist provides us with a full story of the ARP-Senegal. Jallo arrived in Cairo from Senegal as a student in 1966 and took a leading role in the Pulaar movement in the Middle East. A prolific writer, he was the author of several literary works, including two epic novels - Ndikiiri Joom Moolo and Mammuddu Mbuldi Bul kassum. He was a key actor in the establishment of the then Cairo-based Kawtal janngoobe Pulaar e Leydeele Aarabeebe, which he always sought to expand and include all Fulfulde speakers from the West African Diaspora living in the Middle East and in Europe. Jallo created the Cairo-based Fulfulde broadcasting service that was aired throughout West Africa for twelve years, from 1968 to 1981. A professor, researcher, writer, journalist, storyteller and specialist in oral traditions, Yero Dooro Jallo's contributions played a pioneering role in transnationalizing the Fulfulde cause. Subsequently, he was also at the forefront of the transnational Fulfulde organization, Tabital Pulaagu International (TPI), an organization launched in 2002 in Bamako, Mali. This organization, as will be discussed later, represents Fulbe people living in fourteen West African countries and the Diaspora, namely, in Europe, the USA and Asia.

Upon Yero Dooro Jallo's return to Senegal, he continued his militancy around the promotion of national languages in general and Pulaar in particular through his broadcasting service, which he transferred from Cairo to Dakar. Jallo played a leading role in the recreation and recognition of APR-Senegal as a national Pulaar association in 1982 by Senegalese public institutions. In 1990, a small non-profit publishing company called Associates in Research and Education (ARED) was established and began to publish books in Pulaar.

The political climate in Senegal provided a far more stable environment for Pulaar activists, especially after the 1989 Senegal-Mauritania conflict. Desertification and the struggle for basic resources - namely land and water - were at the root of the Senegal-Mauritania conflict, a crisis that some refer to as a Black Mauritanian-Arab Mauritanian conflict. Arab pastoralists were forced to push south towards both banks of the Senegal River, an area entirely occupied by sedentary black farmers. Mauritania used the crisis as an excuse to expel about 30,000 black Africans. The majority of these people were in fact Pulaar citizens of Mauritania. Entire villages previously inhabited by blacks were cleansed. Among those targeted and expelled from Mauritania were Pulaar activists who were considered a potential obstacle to the Mauritanian Arab government. It is in this context of political crisis that the Pulaar movement became a much more forceful trans-border public network that transcended political boundaries, thanks to a common language and common cultural heritage. 
Prior to French presence in the region, Arabs dominated the region since the fall of Ghana in the eleventh century, forcing many of the blacks such as the Sereer group of present-day Senegal who lived in parts of Mauritania to flee further south. There exists tangible evidence that blacks from various ethnic groups were the first people to live in the region. This situation changed during French colonial rule, when colonial Mauritania depended on colonial Senegal both administratively and economically. After both countries gained independence in 1960, Mauritania became and remained a buffer between the Maghreb and Black Africa (Parker 1991). Throughout its existence as an independent state, Mauritania has, for the most part, not been able to govern effectively a mixed population of Arabs, Haratines and black populations including Pulaar, Soninke and Wolof ethnic groups. The country's arabization programme has deepened its internal racial divisions.

The government's mistrust of Pulaar activists goes as far back as 1966, following its decision to make Arabic a compulsory language in secondary schools. There were strong reactions from the Pulaar community and other ethnic black Mauritanians against such a decision, leading to the merger of three black underground parties to form the African Liberation Forces of Mauritania (FLAM) in 1983. What followed were a series of arrests, jail sentences and a more general purge of Pulaar militants.

Activism around Pulaar became the medium through which Pulaar populations could express their frustration against the Mauritanian government's racist political regime. Fagerberg-Diallo (2001) notes: 'Acute political problems inspired the development of both writing and literature in Mauritania, perhaps best remembered for the galvanizing poetry which was well known on both sides of the border' (p.161). The Pulaar movement in Mauritania had a substantial impact in Senegal especially, following the 1989 Senegal-Mauritania crisis. According to Fagerberg-Diallo, when the crisis broke out, the deportations from both sides resulted in an influx to Senegal of professionally trained teachers in national languages from Mauritania, which had a major impact in the professionalization of teaching in Pulaar in Senegal.

Beside the movement around Pulaar literacy, the Senegalese media also had an impact on both sides of the border during the crisis, especially in Senegal where there existed a free open Pulaar press. While the two governments at first played down the crisis and stressed the need to guarantee the security and well-being of foreign communities, various Pulaar radio programmes played a major role in raising awareness about the plight of black Mauritanians. As some have argued, a vociferous Senegalese public opinion was very influential and forced both governments to take the crisis more seriously. Mauritanian journalists, such as Amadou Sarr, who were deported were given opportunities to voice their opinions through various 
media sources in Senegal. Other Mauritanian activists, for instance Murtudo Diop and Saydou Kane, found refuge in Senegal and joined the Pulaar movement there. As a result of their combined activities and initiatives, a greater number of Pulaar radio stations flourished in Senegal during the postconflict years.

Such development of free media fuelled a stronger public opinion and a rapid mobilisation of Pulaar movements and associations from both sides of the border and beyond. These networks functioned independently from the State and constituted a major factor in the emergence of a civil society whose influence in the public domain transcended political boundaries. Other key players in this context of political crisis were religious leaders. They represented a very important part of civil society and played an influential role in the political sphere. Senegalese Pulaar marabouts in particular - whose disciples lived on both sides of the border - had an informal, though important, function in reducing tensions.

Although the Pulaar grassroots movements in Senegal and Mauritania operated within two different social and political environments, they shared the same goals and influenced each other throughout their history. The political crisis of 1989 created a momentum for both movements. Today, the movement around the promotion of Pulaar language and culture has expanded its activities and joined other Fulfulde networks. These networks are perfect examples of structures that operate beyond the purview of the nation-states and provide us with an emerging paradigm for rethinking African integration.

\section{An Emerging Fulfulde Transnational Network}

Today, there exists a wide range of Fulbe networks in every part of the world. Fulfulde websites, internet radios and online newsletters abound throughout the Fulbe diaspora, creating what may be called a virtual transnational and global Fulbe space. This however does not imply that Fuflfulde transnationalism is a new phenomenon. The Pulaar association movement started as a diaspora movement in Arab countries that later spread to Europe. Throughout the 1960s to the 1980s, activists such as Yero Dooro Jallo undertook concrete initiatives geared towards trans-nationalising the movement. There is however no doubt that the current rapid development of new information technologies and the increasing expansion of Fulbe diaspora populations globally have created the resurgence of a far larger Fulfulde movement, with far more organized structures.

The largest and most active Fulfulde organization is Tabital Pulaagu International (TPI). This transnational network is an umbrella organization of Fulbe peoples' associations under the same name in exactly fourteen countries in West and Central Africa and in the Fulfulde diaspora, namely in 
Asia, Europe and North America. The idea of creating a federation of various Fulbe associations came about in 1998 during a Fulfulde cultural festival in Mali. Four years later, in 2002, Tabital Pulaagu was born in Bamako under the impulsion of the Senegalese writer and former minister, Cheikh Hamidou Kane and the Cameroonian hydrologist and businessman, Kadry Yaya who served as the first president of the organization. At its inception, the official headquarters of the organizations was Yola, in Eastern Nigeria. Yola has a historical and symbolic significance, as it was the capital of the Fulani Sokoto Empire in the nineteenth century.

As indicated by its name, the primary goal of TPI is to safeguard and propagate Fulfulde language and culture. Indeed, Yero Dooro Jallo's long standing hope to create a pan-African and pan-Fulfulde organization was rooted in Pulaagu, which refers to the sum of Fulfulde values. He was convinced that there existed a single Fulfulde identity and was committed to promoting the creation of a movement such as TPI. Jallo served as the vicepresident of ARP/TPI, the Senegalese branch of the organization, until his death in 2006.

Since its creation, the organization has worked on the challenging task of harmonizing the various Fulfulde dialects and standardizing their alphabets. This initiative was deemed extremely necessary in order to facilitate communication between various Fulbe groups. TPI is currently working on identifying universities, research institutes, publishing companies, television and broadcasting services worldwide that are interested in the promotion of Fulfulde culture (Pulaagu Magazine 2008). From this perspective, and based on conversations held during the March 2008 annual Festival in Dakar, members of the organization began harmonizing the various Fulbe groups and Fulfulde dialects. Now, in place of the terms Fulani, Haalpulaar, Peul, Toucouleur, Pullo Macina, Pullo Jeeri, etc, the term Fulbe is used to refer to the people and Fulfulde for the language.

Although TPI is primarily a cultural association with the objective to defend and promote Fulfulde language and culture, it has grown into a global Fulbe civil society that seeks to inform and raise awareness about real socioeconomic issues that affect Fulbe people globally. This emerging Fulbe civil society transcends political boundaries and is becoming increasingly transnational. For instance, at the 2008 Tabital Symposium on Sustainable Development and Globalization, scholars, policy makers and government officials representing all of the Fufulde diaspora debated and exchanged ideas about important issues concerning Fulbe people such as the effects of climatic change on Fulbe pastoralists, Fulbe women and sustainable development, and clandestine immigration. These challenges as well as other pressing issues such as conflict resolution and trans-border cooperation, regional and 
transnational development programmes for poverty alleviation, are not exclusively Fulbe problems and are relevant to other African communities.

At a more formal level and as an example, the challenging issue of pastoralism, which affects the lives of most Fulbe peoples and several other groups throughout the continent, has recently forced the African Union and the United Nations Office for the Coordination of Humanitarian Affairs to formulate a continent-wide policy framework on pastoralism in Africa. Pastoralism has also been a key issue in Tabital's agenda, and any formal institutional policy geared towards addressing the humanitarian and development challenges of pastoralist communities should involve the voices of civil society groups such as Tabital.

\section{Conclusion}

As we rethink the transnational public sphere, we must understand that it does not correlate with a particular public opinion operating within a specific national citizenry in order to influence the power of the state. A pertinent question one should ask, then, is to what extent does any transnational movement have the political force to influence individual states' political power in order to translate their initiatives into tangible and concrete solutions that would respond to the multiple challenges of African countries and communities?

At present, there exists a momentum in the debates around efforts to establish closer economic and political ties between Africa's multiple countries. It is clear that there exists a renewed impetus to establish closer economic and political ties among the continent's numerous countries. A good number of economic communities have been formed across the continent, and the political and security dimensions of integration are being put on the agenda of many regional and sub-regional institutions. Factors such as trade integration, the development of roads and other infrastructure, as well as the strengthening of regional institutions, are often identified as key to the integration process in Africa. However, to ensure greater accountability and popular involvement, there is also an urgent need for a more grassrootscentred regional integration in Africa. Indeed one of the major weaknesses of regional integration schemes in Africa has been the lack of grassroots representation and engagement. Besides the important role African leaders and elites have to play in the process of integration, it has become clear that marginalized groups such as women, youth, religious or traditional leaders must engage in the process of integration.

A key element in the process of African integration is the existence of a civil society operating across national African boundaries and its their diasporas. The notion of a transnational African sphere with an active transnational civil society may in fact seem like an illusion and is yet to 
emerge. However, as the transnational Fulbe movement shows, the potential role - whether formal or informal - that people and their organizations play, constitutes an extremely necessary element in the African integration project. Similarly, the role of trans-border languages in re-imagining a transnational public sphere and in achieving the ideals of African integration is certainly undeniable.

In fact, the role trans-border languages could play in the African integration project extends beyond the confines of promoting cultural revival and cultural identity. In the context of African regional integration, trans-border languages have an extremely important role to play both politically and economically. Efforts to bring people who speak the same language across national boundaries together could translate into positive political implications between nations. Besides, such efforts could also help reinforce socioeconomic ties between countries.

\section{References}

Ade-Ajayi, J.F. and Crowder, M., 1972, History of West Africa, New York: Columbia University Press.

Bâ, A.H., 1972, Aspects de la civilisation africaine, Paris: Présence africaine.

Bamgbose, A., 1991, Language and the Nation: The Language Question in SubSaharan Africa, Edinburgh University Press.

Chumbow, B.S., 2005, 'The Language Question and National Development in Africa', in Thandika Mkandawire ed.

Fagerberg-Diallo, S., 2001, 'Constructive Interdependence: The Response of a Senegalese Community to the Question of Why Become Literate', in D. R. Olson and N. Torrance, eds., The Making of Literate Societies, Oxford: Blackwell Publishers.

Gueye, T.Y., 1983, Rella, ou Les voies de l'honneur, Dakar: Nouvelles Editions Africaines.

Habermas, J., 1991, The Structural Transformation of the Public Sphere: An Inquiry Into a Category of Bourgeois Society, Cambridge, Massachussetts: MIT.

Jallo, Y.D., 1993, Ndikkiri Jom Moolo, Ndakaaru [Senegal]: Goomu Winndiyan koobe Demde Ngenndiije.

Kane, A.E., 1999, Markere, Dakar: Nouvelles Editions Africaines.

Kane, C.H., 1961, L'aventure Ambigue, Paris: Julliard.

Kane, C.H., 1995, Les Gardiens du Temple, Paris: Stock.

Kestleloot, L., 2001, Histoire de la literature negro-africaine, Paris: Karthala.

Mkandawire, T., ed., African Intellectuals: Rethinking Politics, Language and Gender in Africa, London: Zed Books. 
Mohammadou, A., 2000, 'Nouvelles Tendances en Littterature Peule', in U. Beaumgardth and A. Bounfour, eds., Panorama des Litteratures Africaines, L'Harmattan/INALCO.

Parker, R., 1991, 'The Senegal-Mauritania Conflict of 1989: A Fragile Equilibrium', Journal of Modern African Studies, 29 (1): 155-171.

Pulaagu: Revue de Prestige du Festival des Arts et de Culture des Foulbes, Edition Speciale 2008, Dakar: Imprimerie Graphi Plus.

Seydou, C., 2000, 'Literature Peule', in U. Beaumgardth and A. Bounfour, eds., Panorama des Litteratures Africaines, L'Harmattan/INALCO.

Tocqueville, A. de, 2000, Democracy in America, Chicago: University of Chicago Press. 